\title{
Balkanologie
}

Balkanologie Revue d'études pluridisciplinaires

Vol. III, n² | 1999

Volume III Numéro 2

\section{Defining South-Eastern Europe}

\section{George Schöpflin}

\section{OpenEdition}

Journals

Édition électronique

URL : http://journals.openedition.org/balkanologie/743

DOI : 10.4000/balkanologie.743

ISSN : 1965-0582

\section{Éditeur}

Association française d'études sur les Balkans (Afebalk)

\section{Édition imprimée}

Date de publication : 1 décembre 1999

ISSN : 1279-7952

\section{Référence électronique}

George Schöpflin, « Defining South-Eastern Europe », Balkanologie [En ligne], Vol. III, n² | 1999, mis en ligne le 22 juin 2010, consulté le 17 décembre 2020. URL : http://journals.openedition.org/ balkanologie/743; DOI : https://doi.org/10.4000/balkanologie.743

Ce document a été généré automatiquement le 17 décembre 2020.

(c) Tous droits réservés 


\title{
Defining South-Eastern Europe
}

\author{
George Schöpflin
}

1 The question of South-Eastern Europe raises the central difficulty of definitions. How is an area or topic to be defined in such a way that it has consistently valid characteristics and the area so defined is distinct from others? This requires the establishment of boundaries, which both include and exclude and, correspondingly empower and disempower. But that is only one half of the problem. The other is to identify the shared structures that define the area. This point is crucial. Structures are universal, while the content may be quite diverse. Many people are misled by this polarity between structure and content. They look at the content and conclude that what they are seeing is unique. In a way they are, indeed, unique, but the underlying structure makes comparisons possible. That in turn means that in any attempt at defining an area, in our case South-Eastern Europe, we must first seek to identify the structures that are shared. That is what makes comparative work possible and legitimate and, at the same time, demarcates the area from others. Indeed, this identification of the structure is vital. Without doing so, we can easily become captives of our own data and end up collecting piles of fascinating but trivial information that we are unable to contextualise.

2 Let us look next at the problematic of South-Eastern Europe. How are we to define an area, or a community? It must have certain shared characteristics, notably established boundaries, geographical and non-geographical, that are recognised and recognisable, but geography on its own is not sufficient - geography is not destiny. Indeed, in many ways looking at a map and seeing a certain geographical unity is misleading, in as much as a map is no more than a representation, a scientific metaphor for physical and other realities. There is a clear tendency in a certain range of historical and political analysis to assume without further scrutiny that geographical unity must also involve other kinds of unity. It is vital, therefore, in defining an area that all shared characteristics, not just geographical - let alone cartographical - boundaries be assessed.

In order that these boundaries be regarded as real, they must include and exclude and must empower and disempower. Then, the greater the number and variety of overlapping and mutually reinforcing boundaries, the better they will resist 
penetration and the stronger will be the identity that it contains. Thus the more powerful the boundary, the more successful it will be in creating an internal coherence - a process that takes place in continuous interaction with the boundary and the boundary traffic from outside. This is the sense in which geographical definitions on their own say very little ; there must be cultural, historical, linguistic, administrative, political boundaries functioning cumulatively to establish lines that are very difficult to cross. Time-processes operating over time generate recognisable patterns, a longue durée, by making these processes a part of what the community comes to regard as "normal and natural", as a part of its world of implicit assumptions. Overall, communities within such boundaries acquire shared habits in their ways of life, shared ways of solving problems, defining strategies and understanding experiences. They acquire membership of a shared web of meanings and reproduce the shared thoughtstyles and thought-worlds that are built upon these processes. These are real communities, with well established qualities that are continuously reproduced and giving rise to cultural norms.

Cultural norms establish a set of rebuttable presumptions often encoded in the implicit world of doxa, the cultural grain. These norms are not absolute and not deterministic, it is always possible to go against them, but that makes matters harder, it is more difficult to legitimate ideas if they are deviant in terms of established cultural norms and the potential to revert to the status quo ante if innovations go against the grain is high. Change imposed against the grain of cultural community will certainly change it, the act of resistance produces change, but the imposed change will always be seen as alien, as abnormal. At most what will emerge is something hybrid and hybridised. This, after all, was the outcome of the communist experience.

5 The Enlightenment state, the modern rational and rationalising state, is an extraordinarily powerful instrument. It has the capacity to create order, meaning, security amidst ever greater complexity and at best it can generate good governance, transparency and accountability. It can integrate social and political action to prevent it from creating chaos or degenerating into anomie, while simultaneously making provision for individual choice. It exists as a concrete reality and as symbol, particularly in its ideal-typical form.

6 It was in this form that it was exported to South-Eastern Europe. This is significant, because it means that it had its origins and contours in a different cultural matrix, a culture with different cultural capital. Hence it was received in the region in a complete form and had to compete against the local pre-existing thought-worlds and thoughtstyles. The two have been at odds ever since. The fit between the modern state and the varieties of the South-East European thought-style has never been a good one, though that has not prevented the South-East European polities from retaining the aspiration to enrooting the modern state in its received Western form.

7 What, then, are the tensions ? First, the reciprocity of rights between rulers and ruled, a very deeply encoded pattern under Western Christianity and feudalism, establishes a counterfoil to the bureaucratic norms of the modern state, which is predisposed to see itself as the repository of ultimate rationality. Alternative perspectives, alternative rationalities are vital in ensuring that the state does not become the captive of its bureaucratic norms and be ensnared by them. Reciprocity here means feedback and self-limitation. None of these is well established in South-Eastern Europe. If anything, 
the state continues to be seen as the key agent of transformation, possibly even the pre-eminent agent of transformation.

Then, in South-Eastern Europe the complexity of social structures is not matched intellectually, cognitively or semantically by society and social knowledge. Modernity was taken over by the state rather than by the society that had still to be modernised when the reception occurred, leaving the state the primary agent of modernisation in a dominant position over society, thereby reproducing the problem, because society finds it difficult to take on the state with inadequate information and social knowledge. The state assumes control of modernisation, because it sees itself as supremely rational and seeks to transform society in its own image. Communism was the apotheosis of this. But society resists this, because it does not necessarily accept the vision of the state as its own. The outcome is an uneasy hybrid, with contrasting and contradictory aspirations and thought-styles in conflict. All of this gives modernisation a bad name, a teleological and alien quality, something programmatic over which society has little control. The consequence is passivity and not the civil society upon which the democratic state is predicated. In this sense, modernisation from above becomes a moral issue.

9 Third, this means that the legacy of the pre-modern networks of power becomes significant in understanding South-Eastern Europe, together with the entire cultural capital of the region. The networks of power and the forms in which power was exercised, the style of public pronouncements, for instance, are reshaped by the coming of modernity, but they do not vanish entirely. The way in which power is exercised, notably in the existence and authority of patron-client networks or the persistence of informal regulation over formal, can bring about a subtle metamorphosis of institutions and make them operate in ways not intended by their original founders.

Further, there is the problem of secularisation, which was a central aspect of Enlightenment rationality, in that early modernity was defined against religion if it was defined against anything; but secularism has a very different resonance in nonWestern Christianity, where the secular sphere has never been as sharply differentiated as in the West. Some of the cultural capital conserved from the premodern past in South-Eastern Europe is clearly the residue of religion and these residues are different from their equivalents in the West.

11 The question then is, can there be a South-Eastern European model of modernity? The answer is yes, but it will have to be constructed on the basis of South-Eastern European thought-styles and thought-worlds, practices, traditions rather than by a mass importation of ideas and patterns from elsewhere. If that means giving greater saliency to ethnicity or hierarchy or whatever, so be it. The alternative will not work very well. The key structures of modernity - complexity, change, contests for power - are the same as anywhere else, but the South-East European content will be different from that of the West.

In theorising the nature and quality of South-Eastern Europe as a whole, we should try to identify the series of shared experiences, patterns and structures operating interactively, generating particular types of collective meanings and cultural capital.

13 The area has had an experience of a particular type of imperial rule - different from the West - based on alien and unpredictable forms of social knowledge and power, alien patterns of exclusion and alien legitimation. Thus the Ottoman legacy tended to emphasise timelessness, changelessness, the futility of individual endeavour, and 
centrally this mode of exercising and legitimating power lacked a model of far-reaching change consonant with South-Eastern European expectations. Power was sacralised in an alien way. The modern state has been constructed against this legacy and necessarily took on some of its features as contestants invariably do ; that opposition in turn became the primary resource for the modern state and the coherence that it sought to create.

The system of administration created by the Ottoman imperium was highly oppressive and arbitrary. It had no concept of a public sphere or public good. Taxation excluded all reciprocity and little to nothing was returned to those who were taxed. It was also inefficient. It gave the individual and the community minimal protection in terms of law and policing and it was remote, opaque and non-responsible. The states constructed on this legacy took over some, not all, of these features and reproduced them. The local élites that lived under this imperium were weak and the styles of power constructed then live on in an attenuated form and are reproduced in modernity.

Peasant subsistence agriculture creates weak models of the future. All resources, nonmaterial as well as material, are treated as zero-sum, there is very little surplus given the marginality of much of the land and the low level of skills, collective cultivation of the land undermines individual initiative and the area suffered from remoteness from the market. Adult illiteracy was widespread in the absence of a religious or educational tradition that stressed adult participation in either church or etatic institutions.

The area shares certain myth structures, notably the antemurale myth of being the last bastion of the West against the East, the myth of victimhood and betrayal by "Europe", a mythic compensation for that suffering (Kosovo is the most obvious case in point), as well as a myth of imperial oppression as justification for time lag and perceived backwardness.

17 Religion creates recognisable thought-worlds and thought-styles. Orthodoxy and Islam, the dominant religions, interacted with Western Christianity directly and indirectly and regarded themselves as threatened centres of moral virtue. Religion establishes a shared world of rituals and cognitive norms, a particular conception of sacred time and sacred space, a set of moral regulations and sense of order. These bring their own cultural capital with them. The question is what kind of thought-style emerges from Orthodoxy and Islam? In general, these thought-styles privilege the collective over individual responsibility, encode a strong sense of hierarchy, pronounce nonnegotiable truth claims, offer weak cognitive models of change and radical rather than incremental change, through the idea of redemption and salvation.

18 The strength or weakness of urbanisation is a key variable. The city functions as the locus of continuous change and exchange, but in South-Eastern Europe it has been weak, static, small and ruralised; it seldom had the capacity to integrate the surrounding countryside. Then, the South-Eastern European city was massively ruralised with communist modernisation, something that it has still to overcome. Furthermore, the communist models of urban integration offered little or nothing to these newly arriving rural masses that would allow them to weather the trauma of the rural-urban shift and to come to terms with the dynamic diversity that the city creates. If anything, communism offered counterproductive models, that of "the classless communist man", which was static and empty of content in the context of various forms of the real social stratification and interactions that people encountered. 
19 It is worth adding here that pre-modern models of ethnic coexistence in pre-modern cities like Sarajevo, say nothing about modern ones, for in modernity the nature of power, of complexity, of resources, of contest are utterly different. There are many who think otherwise, but this is idle dreaming. Where urban cognitive and behavioural models have existed, they were inadequate or swamped so that the city failed to emerge as a locus of civility.

Finally, why is South-Eastern Europe different from Central Europe, why has Central Europe proved more readily integrable into Western Europe than South-Eastern Europe? Some of the answers should follow from the foregoing. Central Europe has better state capacity, superior ability to adjust to and accommodate postEnlightenment requirements, its thought-worlds are closer to the Western European norm (because of the legacy of Western Christianity) and is thus better able to cope with the diversity that modernity generates. This does not mean that Central Europe is possessed of some inherent virtue as some South-East Europeans occasionally suggest, but that the criteria of integration were established in the West and Central Europe, despite its self-characterisation of intermediacy, has been structurally closer to those Western criteria than South-Eastern Europe.

\section{AUTEUR}

\section{GEORGE SCHÖPFLIN}

George Schöpflin holds the Jean Monnet Chair in European integration with reference to Central and Eastern Europe at the School of Slavonic and East European Studies/ University College London. 